\title{
Secularism and the Problem of Sincerity: A New Approach to Ritual
}

\author{
Adam B. Seligman
}

This paper seeks to reframe somewhat the way we conceptualize issues of religious identity in the contemporary world. Rather than the over-used concepts of the religious and the secular, the paper repositions our understanding in terms of ritual and sincerity as useful corrections to an overwhelming emphasis on belief and unbelief as the primary components of a religious and secular consciousness. These later are seen as rooting in a very particular Christian understanding of what religion is about. The paper further posits a correlation between certain modernist orientations and the sincere outlook, while arguing for the continuing importance of ritual in teaching us how to live in a fractured reality.

Adam B. Seligman is Professor of Religion at Boston University and Research Associate at the Institute on Culture, Religion and World Affairs there.

\section{Introduction}

Sometime before his tragic and terribly premature death, I asked the Italian sociologist Massimo Rosati what he meant by post-secularism. The term was becoming current in the literature and I was never fully sure what it referred to. ${ }^{1}$ Rosati gave a brief but precise answer. Post-secularism was the condition in which secularism could no longer take itself for granted. That is to say, in a post-secular reality, secularism was itself subjected to a critical and reflexive gaze, no longer remaining the taken-for-granted "ground" upon which scholarship and analysis of other alternative - and perhaps competing - phenomena could be carried out. What was true for analysis was of course true for life as well. One could no longer simply assume the secular as the ground of existence - as the increasingly shrill debate over religion and secularism is indeed making more than clear. Fifty years ago no one felt called upon to defend secularism or point out the delusionary nature of a belief in God. ${ }^{2}$ The secular world was, transparently, the world, and little was made of this fact: nor was it - except in very circumscribed circles argued about.

1 Rosati (et al. eds.) 2012.

2 Dawkins 2008. 
For most of us of a certain age, the secularism of the State, the civic sphere, the public square, not to mention of political and moral thought was indeed a takenfor-granted aspect of our lives. And even if some of us were raised within more self-contained traditional - what many would call religious communities or sent as children to denominational schools - we were aware that we were the outliers and each of us found their own way of squaring his more personal experience with the world of newspapers, adult conversations and sports competitions. All this has of course now changed and the issues of religion and secularism are debated and discussed in both popular and scholarly forums, providing endless content for print and digital media; positions are taken, calls to action promulgated, loyalties demanded and appropriate anathemas hurled at the opposing side.

What I would like to do in this essay is to extend Massimo Rosati's insight into the self-reflective nature of post-secularism, and encourage us to adapt such reflection not only towards the idea of secularism, but to the very concept of religion itself, as well as to related concepts such as modernity and tradition. Along these lines, I would like to raise the possibility that the very use of a religious/secular dichotomy is not a particularly helpful one, as we struggle to understand the challenges of social life in our contemporary world. We tend to use the concepts of religion and secularity, secular culture or secularization as if these were objective, universal and value-free concepts that can be used to characterize aspects of shared social life that are not religious. Religion and religious, too, are used as universal, objective and value-free concepts. I believe this approach is fundamentally flawed and we need to further explore the particular baggage they come with in order to properly proceed with any inquiry into the changes and challenges we are now facing.

\section{Challenging our Conceptual Framework}

We must begin by recognizing that both religion and secularism are concepts that developed in a very particular and Western Christian context; they are helpful in the sense that they can be used to describe aspects of and the potential for development of future periods in which Christian civilization will take one form but they do not actually serve us well when it comes to discussing, analyzing and understanding other traditional civilizations or other civilizations within which tradition is changing and being re-negotiated. What, for example, is a secular Jew? What about a Jew who observes no commandments, goes to the synagogue only on Yom Kippur and does not otherwise maintain any traditional practices? Is he secular, or partially religious, or what? How do we characterize China and 1.3 billion Chinese? Ingelhart has called China the most secular country in the world. ${ }^{3}$

3 Inglehart 1998. For other sources on Chinese religion today see: Madsen 2011, pp. 17-42; Chau 2006; Yang 2011. 
But look at the proliferation of spirit cults and other forms of worship. Surely this is not secular in any usual sense of the term. ${ }^{4}$ What of the case of Islam? What of the individual or community whose observance of traditional commandments is partial, or almost non-existent? What of the Moslem who eats during Ramadan but only in private, in hiding, away from the communal eyes? Is he secular or hypocritical? What about someone who does not eat during Ramadan but does drink wine occasionally? What of those communities in Central Asia who celebrate the Id, by drinking vodka? Are these people secularists or sinners or ignorant? Or are they like so many others, engaged in the never-ending movements, interpretations and transformations of their respective traditions, which are continually being negotiated and re-negotiated by communities and individuals over the course of time.

In fact, I would claim that secularism refers to a very particular moment in the Western Christian process of negotiation of its own tradition - as was the Protestant Reformation and as is the phenomenon of Christian fundamentalism. All of the above are particular moments in the way the concrete practice of tradition mediates, transforms and negotiates the tradition of practices that define any civilizational endeavor. That a particular moment of this negotiation in the Western Christian tradition is understood in terms of secularism has much to do with the privileging of belief over practice, of faith over works and of Innerlichkeit over external practice that has been part of Christianity from its origins (as evinced in its rejection of Jewish Law and its unique allegorical way of reading and interpreting scripture) and which received particular emphasis during the Protestant Reformation of the $16^{\text {th }}$ century. Secularism as unbelief is thus the complement of tradition understood primarily in terms of belief rather than practice. The resulting use - I would say misuse - of this term - to characterize other civilizational endeavors, the Jewish, the Islamic, the Hindu, etc. - simply represents the spoils of war, as it were: a consequence of the power differentials between the Christian, Jewish, Islamic, Indian and Chinese civilizations. Indeed, as I have already hinted at: I would much prefer to replace the dichotomy of religion/ secular with that of tradition of practices/practice of tradition - this being more structural, less particularistic, historicist and Whiggish a way of conceptualizing what is usually understood as the dichotomy between religious and secular individuals, cultures and communities.

Western Europe, as we recall, is the "secular" exception in a world that is overwhelmingly "religious". Or, in the terms I am offering here, the Western European civilization is one in which traditional practices have been most abandoned and rejected: a fact that can be ascertained by visiting any of the Churches of Western Europe and calculating the average age of those in attendance on any given Sunday. Indeed, as research such as that carried out by Diehl and Koenig seems to indicate, assimilation and acceptance into Western

4 Weller 2004, pp. 285-314. 
European society may well hinge, at least for some immigrants, on their abandonment of previous religious commitments and ways of life. ${ }^{5}$

Moreover, this rejection of tradition is intimately tied up with the overwhelming terms of collective identity. In fact both phenomena may well be related. The Peace of Westphalia and the concept of cuius regio eius religio may be central here. Europe, which was Christian, became a continent of nation-states, and traditional practices were subsumed in different ways within the newly developing national identities. ${ }^{6}$

Parenthetically, I would like to remind the reader that the USA may well be, as S. M. Lipset claimed the "first new nation"; but it is also a nation where certain sectarian Protestant assumptions on self and society were allowed to develop relatively free of the effects of the Counter-Reformation, and of the need to take into consideration the existence of the Catholic Church in general. ${ }^{7}$ The grand debate (often violent to be sure) regarding the terms of Christian tradition that defined the Protestant Reformation and the Counter-Reformation in Continental Europe - and which eventuated in the development of secular polities and societies there - was, to a great extent, ignored in the New World and played but a minor role in the later history of the United States. There was no ultramontane party in $19^{\text {th }}$ century American politics, nor was there a State Church as in Sweden, nor was there a religious requirement for full citizenship rights. All of which does not mean that the USA was, or is, secular. Rather it means that they were a secular country in the classical, circumscribed and medieval sense of the term - referring to that area of public life that is outside sacerdotal regulation and ecclesiastical jurisdiction. Secularism in the USA may then be understood as a constitutional principle rather than a moral position.

I take note of these historical dimensions because they bring us directly to a question of what I believe to be one of the great fallacies of academic research on what we call religious phenomena today - the study of religion in terms of identity. Wherever you go, in conferences and classrooms, in articles and books, religion is understood in terms of identity. This is, in fact, the primary language that social scientists have at their disposal to discuss what goes under the term of religion. As social scientists are not generally the followers of any sacred tradition (except perhaps that of Comte), they can but translate the behavior, attitudes and dispositions they find into language they understand, and the result is our rather simplistic understanding of sacred traditions in terms of the eminently modern problem of identity - whether of individuals or collectivities. Starting from identity we can of course develop increasing concerns with authenticity, funda-

5 Diehl / Koening 2013, pp. 8-22.

6 On religious homogenization as a precondition for national development, see: Stein 1975, pp. 562-600.

7 Lipset 1973. On this issue see also: Lipset 1979, pp. 34-60. See also: Seligman 2008 and Seligman 1987, pp. 90-117. 
mentalism, collective boundaries, value orientations, preferences and a host of additional conceptual categories which are, at the end of the day, nothing but our own attempt to translate a set of sacred practices into the languages of the secular, social sciences.

There is nothing inherently "wrong" with this, other than that it does not get anywhere near the phenomena that it presumes to explain. An observant Muslim or Jew or Jain or Sikh does not, at the end of the day "do" identity or "do" religion when going about his daily rituals. Rather, he is following a tradition, a way of being: both "halacha" in Judaism and "sha'ariah" in Islam mean way or path. Christianity is also referred to in this way in the Acts of the Apostles. ${ }^{8}$ The fact that today, under the onslaught of modernity and modern conceptualizations many Jews and Moslems also conceive of themselves as "doing" identity (not to mention identity politics) is precisely what has given rise to the phenomena we label fundamentalist. Let me offer a small example from contemporary Britain: Today, quite a few Englishmen and women, of Pakistani parents and of Shiite persuasion are finding themselves increasingly alienated from life in the UK. They detect a new suspicion of them and an emergent reality of intolerance. At the same time, they find it impossible to reassert their ties with Pakistan, as they are no longer Pakistani and Pakistan has no interest in them. ${ }^{9}$ With the ground breaking away under their feet, they are beginning to look to Iran as a locus of identity, in a way not too dissimilar from Jews looking to Zion and the political entity of the Israeli State as a locus of their own identity. This then is a clear example of a religious affiliation, the way of one's ancestors, an answer to the problem of Being, call it what you will - in the process of being transformed into a political identity and articulated accordingly. In Europe, nationalism was built on the ruins of religious sentiment, in many other parts of the world; however, this is not at all the case. As noted above, the Peace of Westphalia marked the breakup of one Christian Europe and its replacement by different national entities and hence identities. ${ }^{10}$ The link between religion and identity is, however, neither necessary nor universal. What is particularly interesting is the growth of that linkage today, within different contexts - like that of Shiites in the UK, of certain Jewish communities the worldover, of many Evangelicals tied to the Republican Party in the USA and so on. This however is a pre-eminently modern phenomenon and we must never lose sight of that. Its origins are not in the sphere of either religion or tradition, but rather in the logic of modernity itself.

But here again, rather than observing the reality in question, we translate it into categories convenient to our way of thinking. What often goes unremarked is the

8 On this see: Cantwell Smith 1990, especially pp. 19-32.

9 Personal communication, Communities Engaging in Difference and Religion, Archive, July 2007.

10 On the links of identity formation and nation construction in Western Europe see: Stein 1975, pp. 562-600. 
fact that the roots of this so-called fundamentalism are of the same stuff as the ideology of the social sciences - that is a secular ideology focused on individual and group identity and the realization or, as with $19^{\text {th }}$ century romantic-nationalism, the expressive realization of both. Hence the suicide-bomber who leaves a note that begins not: bisminallah, that is, "in the name of Allah" - but "in my name and the name of my family". This precisely represents religion as a modern ideology - it shares the same conceptual framework as our own social scientific inquiry. It does not, however, even begin to encompass the meaning or perhaps meanings held by what we term religion, for time out of mind. ${ }^{11}$

For what the term religion referred to before the contemporary period was not a value, not a preference and definitely not an identity. ${ }^{12}$ It was often not even consistent and could only be articulated in clear and discursive terms with considerable difficulty. To this day, for example, there is a synagogue in Istanbul that is only open for daily prayers in the afternoon (though morning prayers are privileged most within the tradition) and where the male congregants put on phylacteries (black wooden boxes containing scrolls observant Jews place on their heads and arms during morning prayers) during these afternoon prayers. There is no ideological, theological or normatively articulated reasoning for this deviance from accepted tradition. This is simply "what they do". ${ }^{13}$ There is a strong pragmatism here. In this particular part of town, the time people can get together to pray is in the afternoon, during a work break, so this is when they do so. And since phylacteries are an important commandment (and have been for more than two millennia), they don phylacteries. Yes, they know that everywhere else people don phylacteries in the morning. They do so in the afternoon, because that is just how things are. There is no great system of ideology; no theological precedents, justifications or even defenses are invoked. This is just how they go about doing what they have always done. It is a particular, what we may wish to term ritualist, response to our life in this world and the existential challenges it imposes. ${ }^{14}$

What is taken for religion by contemporary thinkers, but has been understood by billions of people in the world as their own sacred traditions, is in fact a response to the problem of Being. The fact that most social thinkers today no longer understand this as a problem and a perpetual challenge to the human endeavor leads them to a critical methodological error-for they impute their own etic categories to their informants and treat their own categories as emic ones. They construct great edifices of theory, but the explanatory potential of these theoretical edifices is severely compromised. Essentially, our contemporaries,

11 On the difficulty of secular social sciences of fully grasping religious phenomena see: 2009, pp. 57-82.

12 Mitchell 2007, pp. 351-362.

13 Personal communication, Rabbi Mende, Chabad, Istanbul, December 2006.

14 On ritualism as a way of being in the world see: Seligman / Weller / Puet / Simon 2008. 
working with a model of the self as an autonomous moral decisor - that is with a model of the liberal self - cannot really conceive of a social agent as anything but an entity that either has or does not have something - in this case, choices; or, as an agent who effects actions - that is, who makes things, again - choices. We have preferences and we make choices based on these preferences. The great debates within the social sciences for example concern the sources of these preferences whether in some sort of collective conscience, or in a more Human or perhaps even Hobbesian calculus of individual interests. No one, however, doubts the existence of choice and the autonomy of the agent who chooses. What I have tried to hint at - no more than hint at -in the above remarks is that this in itself is a very particular construction of the self, no more or less reasonable than any other - but one that perhaps leaves us in the dark about the motivations, understandings and existence of billions of individuals, today and in the past, who do not understand themselves to be morally autonomous actors, but rather see themselves as acting out heteronomously imposed norms where the only choice is to observe God's commands or not. And this is a good distance from the type of choice that rational actor theories, or even more culturalist readings of the self, understand to be at the core of social action.

To return to our focus on secularism, religion and identity, I would go so far as to suggest that the very use of the concept of secularism as a contrast to something which is "religious" betrays a particular historical, religious and perhaps even ideological heritage that, of necessity, clouds one's glasses and skewers one's assumptions when approaching the world of social phenomena. We must recall that the very term religion does not exist in other civilizations. ${ }^{15}$ It originated as a concept in Roman law and carries with it a very particular cultural baggage and no end of ambiguous meaning from the late antiquity onwards. Lucretius used it differently from Cicero. In the pre-Christian era it was best understood as an adjective rather than as a substantive (if something was religio for me, it meant that it was mighty incumbent on me to do it). With the Church fathers - Lactantius and, of course, later Augustine - religio really became the way to posit boundaries, and to distinguish between the followers of the true religion (Christianity) and those of false practices and beliefs. It is, if you will, a full-fledged ideology, avant la lettre.

The point of these remarks is thus to emphasize that religious, post-religious and civil identities do and sometimes don't come together in all sorts of interesting ways and we must be very wary of positing a one to one relationship between them, or of reducing the one to the other. Moreover, the multifaceted ways in which sacred traditions and civil identities interweave (or don't) make the existence of multi-ethnic, multi-confessional states and societies somewhat of a

15 Cantwell Smith 1990, op. cit. pp. 19-31. 
challenge and one that has come to define our contemporary world to a great extent. $^{16}$

Here, too, the fact that our categories are rooted in Christian civilizational assumptions - even if they are of a post-Christian nature - is a stumbling block to understanding and leads to all kinds of misconceptions. People may decry or celebrate the "return of religion" in the contemporary world. But is this really the case? Western Europe, which was famed for its secularity, has, to a great extent, remained secular - except in terms of its immigrant population and even they, as we have noted, seem to be under pressure to secularize if they are to be accepted into social life. The churches are still more or less empty, or filled with an aging population; the mosques however are a different story. Here the example of Bulgaria may be instructive. The government in Sofia, Bulgaria is concerned with the proliferation of minarets in the towns and villages spread out all over the Rhodope mountains. Yet closer inquiry shows that most of these minarets, while new, do not in fact reflect a new Muslim population, but rather a "sunnification" of the Alevei population who, under various economic and political pressures, have agreed to place minarets on their Jamyas and otherwise accept Sunni hegemony (at least externally). ${ }^{17}$

And while many of us are transfixed by the violence in the Middle East and the horrific assault on non-Sunni Muslims there, let alone the violence between Shi'a and Sunni Muslim communities that extends to places as far afield as Pakistan and Indonesia (which held a global anti-Shia conference in April 2014), the internal negotiation - sometimes violent but not always - of what it means to be Muslim is carried out across the globe. ${ }^{18}$ From Bosnia to Kyrgyzstan, Toronto to Tashkent different forces, acting in different historical and social contexts continue to negotiate their traditional obligations and understandings of tradition. And while the congregant of the gay and lesbian mosque in Toronto may not feel comfortable in the main mosque in Bishkek they are still both involved in a similar process of negotiation - which is far removed from any simplistic account of secular viz. religious understandings of self and society. ${ }^{19}$ Islam in Kyrgyzstan is, as in so many other places, a site of serious contestation; as traditional forms of Islam, often deeply embedded in pre-Islamic practices, are under assault from very different understandings of Islamic practice, imported by secondary elites, returning from schooling in the Middle East. Here, too, we may claim to witness a process of "sunnification". Yet, the very existence of a gay and lesbian mosque in Toronto

16 Examples from Israel, Cyprus, Bulgaria, Malyasia, Turkey, USA, France as well as a review of the Western European situation are presented in: Seligman (ed.) 2014.

17 Provisional results of field-work currently being carried out in the Rhodope Mountains, CEDAR archives.

18 AlIraqui April 25, 2014.

19 The Star: Islamic scholars experience diversity of Muslim practices at $\mathrm{U}$ of $\mathrm{T}$ summer program. 
speaks to a different type of negotiation, a very different type of turn to tradition, no less important, and with consequences no more predetermined.

\section{Rethinking Ritual rather than Religion}

This negotiation, whatever its many features, does however point in one critical direction towards a re-engagement with ritual action which, in fact, is one of the interesting, if somewhat counterintuitive, developments of the turn of the twentyfirst century. Ritual has been re-emerging among many sectors of society, including religious society, which had previously distanced themselves from ritual acts. For example, we see the reversal of the leaders of Reform Judaism, who have readmitted ritual to their religious practice in response to congregant demands. ${ }^{20}$ We also see the spread of orthodoxies defined in part through ritual action orthopraxies might in fact be a better term - including the growth of Islamic identities in many regions, the worldwide increase of Jewish orthodox practice, and even the attraction in the United States of neo-paganism and Wicca, or the exponential growth of Yoga centers in cities across the country. ${ }^{21}$ The growing concern with a practical theology among mainline Protestant Churches is another indicator of this trend. Similarly, the emergence of various forms of Neo-Confucianism among Chinese intellectuals also focuses in part on the concept of liritual in the broad sense that includes both acts of worship and interpersonal rituals of courtesy and diplomacy. ${ }^{22}$

Given this social development, it may well be safe to say that one of the most dangerous misconceptions, our confusions about post-secularism, secularism and tradition, has given rise to lies in the very basic distinction between tradition and modernity that pervades both the scholarly community and commonsense readings of world history. Such understandings typically include the claim that traditional societies are governed by ritual - that is, by largely unquestioned external norms, customs, and forms of authority that regulate individual lives. In contrast, modern societies are seen as valuing individual autonomy, such that norms, customs, and authority are only accepted through the conscious choice of the rational individual. Fundamentalist movements, according to this same line of reasoning, represent a rejection of the modern world and an attempt to return to a traditional world of ritual.

Yet a strong case could be made for almost every aspect of this framework being wrong. It is based upon a misunderstanding of ritual, a misunderstanding of earlier societies, a misunderstanding of our current situation, and a mis-

20 Freedlander / Hirsch / Seltzer 1994.

21 On the return to Jewish orthodoxy, see: Danzger 1989; on Christian developments see: Browning 1996; and Volf / Barr 2002.

22 Weller 1998; Wei-Ming 1991. 
understanding of movements like fundamentalism. It also leads to a potentially dangerous normative goal - namely, that what we and indeed all societies need is just more individual autonomy. What I wish to do in the remainder of this essay is to explore the idea of ritual action, juxtapose it with a more sincere model of human behavior, and argue for the enduring value of the ritual, in contrast to the sincere. In so doing, I would hope to slightly change our focus from the dichotomy of religion/secular or even post-secular to that of ritual/sincere - as an alternative way of understanding some of the social and political phenomena that are increasingly defining our world order.

To no small extent, our ignorance and lack of understanding of ritual stems from a rather particular reading of ritual and ritual theory. ${ }^{23}$ Much modern ritual theory thinking rests, in fact, on understandings of ritual and religion that began to take their current form with the radical Protestant rejection of Roman ritual during the Reformation of the sixteenth century, and that further developed during the Age of Enlightenment. The most pervasive aspect of this line of thought was to read ritual as an authoritarian, unquestionable, irrational set of constraints on the individual. The academic analogue of such an approach has been a certain reductionism in the study of ritual, such as can be found in the functionalist theories of figures like Radcliffe-Brown. Even the reaction against such a reading of ritual, like the interpretive approach that grew out of Clifford Geertz's work, derives from a post-Protestant and post-Enlightenment framework of the meaning-making individual ${ }^{24}$ Ritual, given such an understanding, seems less authoritarian, but only by positing a belief framework underneath it. Ritual in this reading appears as no more than an outward enactment of inner states of belief.

If, however, we approach ritual from the perspective of other and non-postProtestant traditions, we get a rather different reading. For example, both early Chinese and Jewish writers provide ways of thinking about ritual that differ distinctly from both Protestant and most modern social scientific understandings, and that should themselves be taken seriously as theory. ${ }^{25}$ These views provide a reading of ritual as a subjunctive, as the construction of an "as if" world. While many social scientific theories imbue ritual with a coherent worldview, these other civilizational texts on ritual assume a world that is fragmented and broken. The subjunctive world of ritual resides in inherent tension with such a broken world, and such a subjunctive world is at least implicitly understood to be limited and

23 Most complete reviews of ritual theory can be found in: Bell 1992 and Bell 1997. A useful corrective to much ritual theory in the social sciences can be found in: Rappaport 1999.

24 For examples of this stress on individual "belief" rather than social practice see: Geertz 1973. See also: Talal Assad's critique of this approach in: Assad 1993, pp. 27-54. 25 These perspectives have been developed at length in Seligman / Weller (et. al.) 2008; as well as in Seligman / Weller 2012. 
temporary. Ritual, then, involves the endless work of building, refining, and rebuilding webs of relationships in an otherwise fragmented world. The work of ritual ceaselessly builds a world that, for brief moments, creates pockets of order, pockets of joy, pockets of inspiration. There is, in fact, autonomy in such a work, but it is an autonomy that recognizes the limited and fragmented world in which we always act.

Ritual, as a form of social action, has admittedly been somewhat disparaged in the contemporary world and in the prevailing discourse of the secular, what Charles Taylor termed "the immanent frame". ${ }^{26}$ Yet in its formal, iterated and enacted moments, ritual presents a unique human resource for dealing with existence and with the multivocal nature of all relationships - with beings human and divine.${ }^{27}$ Ritual defines and binds entities, times and spaces, and in such border creating activities. It also links such entities, times and spaces to what is beyond their immediate field. It presents a coherent and embracing way of living in a pluralistic and hence also deeply ambiguous universe, one where order can never really be known, but still must be acted upon. In our contemporary world, ritual has - all too often - been associated with reactionary and anti-democratic politics, with a world view that eschews individual autonomy or even rationality and seems to reject most of the shared values of all "right-thinking" - which often translates into "secular" - folk. Here I will attempt to argue that not only is this understanding of ritual wrong, it contains also a very dangerous and sincere impulse towards totality, one that has characterized much of the politics of the past one hundred years. This impulse took an overwhelmingly secular form in the $20^{\text {th }}$ century - in movements of communism, fascism and Nazism - and is taking a strikingly religious form in the $21^{\text {st }}$ century - in both monotheistic as well as nonmonotheistic traditions - the world over. What characterizes all of these, however, is a striving for authenticity, sincerity, and totalizing politics that reject the essentially fragmented nature of existence and, by implication, the contingent nature of all politics. Ritual action, though often heavily frowned upon in today's world, especially by secular elites, provides an illuminating alternative.

When we say that the members of a culture share a symbol system, or a set of values, or a common idea of the sacred, we essentially assert that they share the potential space of what "could be" a subjunctive world. In fact, much ritual action provides this shared sense of a moral order - sometimes even in terms of an explicitly shared "what if". When Jews convene around the Passover Seder table and are explicitly enjoined to fulfill the commandment to feel "as if you yourselves have been liberated from Egypt" they create that shared space where the communality of the "could be" becomes the very basis of the ongoing collective experience. The Shi'ite enactment of the defeat of Imam Hussein at Karbala and the Catholic participation in the Eucharist are of similar import. Confucius, fa-

26 Taylor 2007.

27 Seligman / Weller 2012, pp. 93-98. 
mously uninterested in the world of spirits, still insisted that when "he offered sacrifice to his ancestors he felt $a$ s if his ancestral spirits were actually present". ${ }^{28}$ When he offered sacrifice to other spiritual beings, he felt as if they were actually present. Maimonides enjoins us to attend to our prayers "as if" we are standing before the Creator of the universe. ${ }^{29}$ The moral community that Emile Durkheim outlined in his The Elementary Forms of Religious Life exists precisely because it shares the potential space of culture created through ritual. ${ }^{30}$ That shared moral community is never the entirety of social experience in its full complexity of misunderstandings, conflicts of interest, and incompatibilities. Instead, it is a subjunctive construct, a shared acquiescence to convention.

In ritual we subject ourselves to externally given categories of order, whose source can be anything from a transcendent deity (as in Judaism) to the natural ordering of the physical and social world (as in Confucianism). Ritual concentrates on the performative nature of the act rather than on its denotative meaning. In fact, pure ritual puts questions of belief or truth aside in favor of the shared world that its action creates and requires. The very external, performative aspects of ritual - especially its repetition and recollection of places and times not given to purely rational or instrumental computation - give it a unique liability. Thus ritual encompasses the ambiguity of life in a unique manner. It allows one to "play" with such ambiguity in a manner precluded by an undue concern with the authenticity of one's actions and beliefs. Ritual unshackles the mind from a need to believe in a dogma of our choosing, as long as we act within its conventions.

Ritual allows us to live with ambiguity and the lack of full understanding. In slightly different terms, it allows us to live with the other, with what we do not fully know or understand - as indeed, we can never fully know or understand any other. The presentation of ritual's "as if" universe, the subjunctive, requires neither a prior act of understanding nor a clearing away of conceptual ambiguity. Performance simply and elegantly sidetracks the problem of understanding to allow for the existence of order without requiring a full understanding of it. In this way, it resembles all manners of decisions we must make to take any concrete action, where we accept that we have as much understanding as we are likely to get and even though it is incomplete (as it always must be), action must be taken. This is true for a medical intervention, a financial investment, a marriage commitment, a declaration of war or the planning of a highway - for virtually all forms of human endeavor. Through its emphasis on action, on the performative and its creation of a subjunctive universe, without demanding a world of shared meaning, ritual creates a world - temporary, fragile to be sure, but not false -, where differences can be accommodated, tolerance enacted (if not fully understood) and openness to the other maintained.
28 Chan 1963, p. 25.
29 Maimonides, p. 4.
30 Durkheim 1995, p. 47. 
While ritual activity carries its own form of intentionality, it is important to note that ritual is not necessarily concerned with what is often understood as sincerity. In any ritual, as with saying "please" and "thank you," performing the act marks acceptance of the convention. It does not matter how you may feel about the convention, if you identify with it or not. In performing a ritual, the whole issue of our internal states is often irrelevant. What you are is what you are in the performance, which is of course an external act. This is very different from modernist concerns with sincerity and authenticity. Getting it right is not, as in the latter cases, a matter of making outer acts conform to inner beliefs, of, as is commonly thought, "meaning" what you say. Getting it right is doing it again and again and again - it is an act of world construction. As an ideal type, the self who performs a ritual is very different from the self who is sincere.

Unlike ritual, the sincere - with which I wish to juxtapose it-is characterized by a search for motives and for purity of motives, reminiscent of Kant's preference of the purity of the moral will. Sincerity privileges intent - and hence, meaning - over action. This concern with intent has become the touchstone of much of our moral reasoning, for instance in Immanuel Kant's writings on the workings of the "good will" ${ }^{31}$ As Kant stresses: "The good will is not good because of what it effects or accomplishes or because of its adequacy to achieve some proposed end; it is good only because of its willing, i.e., because it is good of itself." Thomas Nagel and Bernard Williams cogently delineated the limits of this view in clarifying that: "However jewel-like the good will may be in its own right there is a morally significant difference between rescuing someone from a burning building and dropping him from a twelfth story window while trying to rescue him." ${ }^{32}$ Nonetheless, from the Puritans of the seventeenth century to the talk shows of the twenty-first, a concern with the inner wellsprings of action and its meanings has almost become an icon of modernist culture. The search for the singular and unalloyed (definition, feeling, impulse or intent) is very much at the core of the search for sincerity. ${ }^{33}$

Sincerity, seems by its very definition to exclude ambiguity. Recall that its dictionary meanings include: "being without admixture", "free", "pure", "whole", and "complete". ${ }^{34}$ Samuel Johnson lists among its cognates: "unhurt", "uninjured", "pure", "unmingled", and "uncorrupt". Sincerity, carried to its extreme, is the very search for wholeness, for the overcoming of boundaries and the positing of a unitary, undifferentiated, uncorrupted reality. It is a utopian impulse.

\footnotetext{
31 Kant 1959, p. 10.

32 Nagel 1979, p. 25.

33 The following juxtaposition of ritual to sincerity was explored at length in: Seligman / Weller (et. al.) 2008; Seligman / Weller 2012 and critically explored and critiques by various scholars in a special issue of Philosophy and Social Criticism, vol. 36 (1) 2010. 34 Funk / Wagnalls 1937.
} 
In the continual search to renew the "authentic" sources of sincerity, there is little room for ambiguity. All ambivalence and ambiguity threatens the attempt to arrive at the "true" self. That true self can of course be very different in different times and historical periods. But in each case, sincerity tries to resolve all ambiguity to forge a "pure" and "unsullied" consciousness. Fifty years ago in Russia or China it was the search for a "true" revolutionary consciousness. In the midnineteenth-century springtime of the peoples it was to be at one with the spirit of one's folk, as exemplified in the epic poetry of Adam Mickiewicz in Poland or the Russian orientalist music of Glinka or Borodin. The particular model of the "true" self may change, but the dynamic of ascertaining its presence is everywhere similar. This is a dynamic that leaves little room for ambiguity, for mixed motives and for the complexity and contradictory character of most human striving.

The drive for oneness, for notational wholeness whether expressed in the wish to be at one with oneself and with the world, or for eternal and unchanging truths, will always come into conflict with the reality of existence. A measure of hypocrisy complements any notion of a true self - or any other claim to absolute truths because we can never fully express an inner being - which is, at any rate, never unambiguous - and because any social interaction is mediated by language and other conventions. Shakespeare apparently shared some of this assessment, as we can see from the character of Polonius, in whose mouth Shakespeare puts those lines about "to thine own self be true". He is after all a meddlesome buffoon, not above lying and spying on his betters, full of bombast, self-importance and deceit: a model hypocrite, for his great capacity for self-deception. Single-minded adherence to the "sincere" model of existence in the world does not allow for a somber and realistic vision of just how complicated, contradictory and ambiguous the sources of action, feeling, claims-making and intent really are. Rather, it results in the continual production of a hypocritical consciousness that holds up as a model what is essentially a deeply compromised, narcissistic and unrealizable ideal. It adheres to a vision of wholeness that is not of this world, and attempts to implement it within the world, which has led to some of the greatest collective tragedies of past centuries.

In many cases - in life as in literature - the almost child-like fascination with authenticity, with uncovering the "real" motives for action, the "uncorrupted" fount of feeling or the "pure" state of experience gives way over time. It evolves into a much more somber and realistic vision of just how complicated, contradictory and ambiguous the sources of action, feeling and intent really are. Going one step further, true understanding and creative growth ultimately occur only by coming to grips with this rather unromantic and severely compromised nature of our lives.

In contrast to this, the realization that our boundaries are only artifice and that the world is fundamentally broken - which we can find in a ritual approach allows us to accept and even play with the inherent ambiguity of the world. Ritual in fact, incorporates a degree of ambiguity within its very practice. In moving 
between differentiation and unity, ritual recognizes the ambiguous nature of reality and registers it, rather than denying it. While in some senses ritual searches for wholeness, it does so through recognizing of difference and ambiguity, rather than by denying them. Ritual does more than posit a reality. Rather, its pattern is often the classic dialectic of positing a reality, negating it, and ending up with a "truer" reality. Ritual's opening to subjunctive worlds allows this play with different versions of reality and allows for recognition of the ambiguous nature of empirical reality, in a way that the sincere mode would find threatening and overwhelming.

Anti-ritualist attitudes - including secular orientations - tend to deny the value to this subjunctive of play, convention, and illusion. Their strive for oneness and for a notational wholeness, whether expressed in the wish to be at one with oneself and with the world, or for eternal and unchanging truths, will always come into conflict with the reality of our flawed existence as attested to in the collective tragedies of the past century. Such attitudes reject the fundamental brokenness of the world in a search for wholeness and totality. And while ritual may teach us to accept and even to play with the inherent ambiguity of the world, the very absoluteness of the secular and sincere stance attempts to exclude it.

What we usually call the "modern" period, with its emphasis on the notational impulse and its strong "flight from ambiguity", has given a rare institutional and cultural emphasis to such totalizing claims. ${ }^{35}$ As a consequence, ritual has come to be seen from their perspective, and has come to be relegated in our minds to a supposedly "traditional" order that the modern period has heroically superseded. Indeed, so pervasive have these claims become that even revolts against this socalled "modern" era are carried out in the name of finding ever-more tropes of an authenticity that, at the end of the day, cannot be - and which we would in fact characterize as various types of fundamentalist movements.

These movements are rooted in what Eric Voegelin termed the "gnostic" nature of modernity. By this he meant, the reframing of the soteriological project of what Karl Jasper's termed Axial or transcendent traditions in terms of immanent, human processes that take place within history and within the orders of society. ${ }^{36}$ In Voegelin's terms: "Gnostic speculation overcame the uncertainty of faith by receding from transcendence and endowing man and his intramundane range of action with the meaning of eschatological fulfillment". ${ }^{37}$ In this sense Voegelin relates Gnosticism to the immanent nature of Christianity and shows how "gnosticism was an accompaniment of Christianity from its very beginnings, its traces are to be found in St. Paul and St. John". ${ }^{38}$ However, he most clearly

35 On the modern "flight from ambiguity" see: Levin 1985; on its totalizing nature see: Besançon 1981.

36 On the concept of Axial Age see: Jaspers 1953.

37 Voegelin 1987, p. 129.

38 Ibid., p. 125. 
identifies it with the modernist program of sixteenth-century Puritanism. He saw the quintessentially secular, nineteenth-century nationalisms and twentiethcentury communism, Fascism and Nazism as various forms of such gnostic approaches to political order.

Many of the movements we call "fundamentalist" - whether Christian, Jewish, Islamic or Hindu - are gnostic in this sense. They take a religious, transcendent set of meanings and coordinates and infuse it with nineteenth-century nationalist immanent ideologies to produce a gnostic version of their respective religious traditions. Such movements are quite common in the Middle East, where they characterize both the extreme-right wing of the Israeli settler movement (such figures as R. Ginzburg the Kabbalist) as well as Hamas and Islamic Jihad in Palestine. ${ }^{39}$ They are also prevalent in the Balkans where their ideologies led to the horrific slaughter of the 1992-1995 Balkan wars. They appear as well in some sectors of the Christian fundamentalist movement in the USA.

What characterizes various forms of militant religious fundamentalism - from radical Islamicism to Hindu nationalism to the commitments of the radical religious right in Israel - is in fact an attempt to overcome the ambiguities of existence through the re-imposition of religious categories on all orders of social organization. In this, their search for wholeness and an overcoming of all ambiguities, they are, no less modernist than the political movements noted above. Ridding the Land of Israel of Muslims, or the Dar-al-Islam of infidels, murdering doctors who perform abortions or attacking religious monuments in India (or for that matter, advocating a constitutional amendment that would ban gay marriage) are all attempts to overcome the chasm between the religious terms of meaning, transcendence and unity on the one hand and the simple fact that the taxonomic orders of the world do not, on the whole, recognize these orders of meaning. The teaching of Hindu astronomy in India and the movements to reintroduce animal sacrifice on the Temple mount in Jerusalem among certain Jews in Israel today (seemingly more purely cognitive but having a strong political element) are similar examples of the same dynamic. So, for that matter, is the growth of Christian banking in the USA among evangelical communities, where banker and client join hands and pray together in search of a good mortgage. ${ }^{40}$

Such cases exemplify the contradictory and often debilitating character of those forms of contemporary religious practice that strive for total coherence in a world that, by its very nature, is contradictory and ambiguous. They suffer, as does the "secular", from the conceit of totality conceived of in immanent terms.

39 On this orientation in the Israeli settlement movement see: Fischer 2007.

40 Shorto, 31 October 2004. 


\section{Conclusion}

Both sincerity and ritual are perennial aspects of the human condition. All human civilizations oscillate between them and combine them in various ways. Wang Yangming was no less sincere than Cotton Mather, the later prophets no less than Jonathan Edwards. While both models are ideal types, neither can exist purely on its own terms. Neither can constitute a perduring social order on its own. Each must be continually mediated by the other.

Sincerity taken to its final point would take one totally outside of social order. The model of total sincerity is the anchorite (or de Sade's fictional characters, in a reversal of the theme). The "true" self ends up in the no-self. The self disappears when emptied of its social characteristics - age, gender, status, roles, and all the distinctions of social convention. This of course is the self that we can see in social moments that Victor Turner understood as communitas and Max Weber spoke of as "pure charisma".

Human life, however, takes place within society. Even those who leave society - such as beggar monks, anchorites, and saints (or sadists) - depend on the society they have rejected. Within the orders of life, one must always at some point step back from the extremes of the other-worldly abyss and reengage with the world. However, as soon as one does so, sincerity becomes mediated by ritualized forms of behavior and appropriation. Once clothes are admitted, dress codes follow, once food is admitted, food restrictions (kashrut, hallal, Lent, etc.) follow as well. These are the ritual markers of a subjunctively shared universe. One cannot enter the division of labor without also engaging in all the ritualized aspects of human interaction that both distinguish and unite those involved.

The ritual side has its own constraints. The very necessities of social life restrain the extremes of sincerity, while the very facts of historical/temporal change limit any attempt to organize life solely according to ritual. Time, and thus change, is built in to our existence in the world. Temples are burned down, sacrifices rendered useless, priests slaughtered, and new modes of understanding emerge. All of this challenges the efficacy, indeed the very possibility of ritual. Ritual must then be re-thought, and thus becomes mediated by the reflective processes of sincere reasoning. Change results, invariance is mediated, and actors encode these changes even as they think them through. Recall Franz Kafka's wonderful parable of the leopards in the Temple: "Leopards break into the temple and drink to the dregs of what is in the sacrificial pitchers; this is repeated over and over again; finally it can be calculated in advance, and it becomes part of the ceremony." ${ }^{41}$

This process disturbs the formal order and repositions the frames of the world. It breeches existing limits, tears down constraints, and unpacks clichés to let new meanings emerge. The very openness of the future thus carries the potential to question existing categories and the boundaries through which we construct them.

$41 \quad$ Kafka 1961, p. 92. 
Existing forms are constantly contested and the inherent open-ended nature of this challenge makes the integration of ritual and sincerity an endless project, part of the continuing human enterprise.

In its least efficacious moments, ritual too may deny change, mutability and the perduring contradictions of the world. It too may attempt to posit a unified (and universally applicable) ritual order on all realms of existence. In a number of societies we have seen this in various forms of fundamentalist movements, but also, in different $20^{\text {th }}$ century modernist (and sincere) political movements which sought to bend the ritual order to a purely future oriented trajectory (think for example of the 1,000 year Reich or the communist world standing at the end point of history, "the final battle" in the words of the Internationale).

Enduring social order rests however on some integration of a future orientation (replete with its strong element of change and risk) with a perception of a shared past - of ties that limit, circumscribe and define, and hence give meaning. Communities cannot be totally future orientated affairs. They must always balance openness to the future - which is at its most basic an intergenerational one with commitments tied to a shared past. As Hans-Georg Gadamer succinctly pointed out, the pressure towards ritualization is rooted in the fact that "experience is valid only if it is confirmed; hence its dignity depends on its fundamental repeatability" ${ }^{42}$ Clearly, the relative valence of each is different in different traditions. Christianity is, in these terms, more future orientated than Judaism. A liberal capitalist social order is more future-oriented than a Christian feudal one. But some mix is always present. Some past referent and some future orientation are always part of any culture and every human order.

The impulse to inject the meanings and attributes of sincerity into ritual is beset with danger. It tries to short-circuit the endless play of ritual and sincerity and conflate the one with the other. Reformulating ritual in terms of sincerity works to the detriment of both. We must rather learn to appreciate, or perhaps to appreciate anew, both modes of understanding and to refrain from the impulse towards wholeness, towards the totality that seems to characterize so much of contemporary attitudes to both ritual and sincerity.

My aim here is not so much to advocate for ritual as opposed to sincerity, but to develop a new appreciation of ritual, freed from the contemporary - and most often secular - frames of sincerity. Such an appreciation rests to a great extent on a ritual's formal qualities, rather than its substantive content. As argued above, the repeated, performative and anti-discursive nature of ritual, provides a critical way of dealing with, rather than overcoming, the eternal contradiction and ambiguity of human existence. I am not, however, advocating an unchanging ritual - ritual historically undergoes change, often in response to changed historical and social circumstances. Indeed, ritual traditions typically include mechanisms for effecting change in ritual practice. I am however urging that contemporary attempts to

Gadamer 1973, p. 311. 
make ritual more discursive and more responsive to modern sensibilities must take into account the very features that make ritual a unique resource in the human encounter with the world.

What I try to argue in fact, is that taking ritual seriously can help teach us about the tremendous dangers of trying to build a totally coherent world of notation - of authentic, individual truth-claims. Instead, it can help teach us to recognize the fragmented and discontinuous nature of the world, the endless work entailed in building and refining our multiple and often conflicting relationships within that world, and the ultimately tragic fate of that work. And it helps teach us about the powers of ethical action based upon such a tragic vision. Accepting the world's discontinuities and ambiguities means that the work of building and refining relationships will never end. Ritual, at least in its relationship to the rest of experience, is never totally coherent and never complete. Yet doing the work of ritual is one of the most important ways we live in such an inherently pluralistic world.

The ethical implications of the above argument are numerous. We need to rethink our history, taking it out of the tradition/modernity, or religious/secular dichotomy in which it is so often and mistakenly read, and we need to re-think our normative claims accordingly - once again taking the traditional claims of a ritually ordered life seriously. Among other things, this involves taking other, nonChristian traditions seriously - a move that would prevent us from identifying a particular Christian trajectory with any intrinsic or inherent human or social developmental path. It also should teach us to be wary of our categories and careful in our use of concepts, freighted as they are with particularistic baggage however much that particularistic baggage may make universalistic claims.

Our very categories of secular and post-secular can, as I have tried to argue here, be replaced with a somewhat different grid, to produce a very different reading of social dynamics and the forces at work in so many parts of today's world: in Europe, the Middle East and beyond.

\section{References}

Assad, Talal: Geneologies of Religion: Discipline and Reaons of Power in Christianity and Islam. Baltimore 1993, pp. 27-54.

Bell, Catherine: Ritual: Perspectives and Dimensions. New York 1997.

Dies.: Ritual Theory, Ritual Practice. New York 1992.

Besançon; Alain: The Rise of the Gulag: Intellectual Origins of Leninism. Translated by Sarah Matthews. New York 1981.

Browning, Don: Fundamental Practical Theology: Descriptive and Strategic Proposals. Minneapolis 1996.

Cantwell Smith, Wilfred: The Meaning and End of Religion. Minneapolis 1990.

Chan, Wing-Tsit: A Source Book of Chinese Philosophy. Princeton 1963. 
Chau, Adam Yuet: Miraculous Response: Doing Popular Religion in Contemporary China. Stanford 2006.

Danzger, Herbert: Returning to Tradition: The Contemporary Revival of Orthodox Judaism. New Haven 1989.

Dawkins Richard: The God Delusion. New York 2008.

Diehl, Claudia / Koening, Matthias: "God can Wait: New Migrants in Germany Between Early Adaptation and Religious Reorganisation”, in: International Migration, vol. 51 (3) 2013, pp. 8-22.

Durkheim, Emile: The Elementary Forms of Religious Life. New York 1995.

Fischer, Shlomo: Self-Expression and Democracy in Radical Religious Zionist Ideology. PhD. Dissertation. Hebrew University 2007.

Freedlander, Dan / Hirsch, Robin / Seltzer, Sanford: Emerging Worship and Music Trends in UAHC Congregations. New York 1994.

Funk, Isaac K. / Wagnalls, Adam W.: Standard Dictionary of the English Language. New York 1937.

Gadamer, Hans-Georg: Truth and Method. New York 1973.

Geertz, Clifford: "Religion as a Cultural System", in: Id.: The Interpretation of Cultures. New York 1973.

Inglehart, Ronald: Human Values and Beliefs: A Cross-Cultural Sourcebook. Ann Arbor 1998.

Jaspers, Karl: The Origin and Goal of History. New Haven 1953.

Kafka, Franz: Parables and Paradoxes. New York 1961.

Kant, Immanuel: Foundations of the Metaphysics of Morals. Trans. L. White Beck, Indianapolis 1959.

Levin, Donald: The Flight from Ambiguity. Chicago 1985.

Lipset, Seymour M.: “American Exceptionalism” in: Novak, Michael (ed.): Capitalism and Socialism: A Theological Inquiry. Washington DC 1979, pp. 34-60.

Id.: The First New Nation. New York 1973.

Madsen, Richard: "Religious Renaissance in China Today", in: Journal of Current Chinese Affairs, vol. 40 (2) 2011, pp. 17-42.

Maimonides: Mishne Torah, Hilchot Tephila. Jerusalem.

Mitchell, Joshua: "Religion is not a Preference", in: The Journal of Politics, vol. 69 (2) 2007, pp. 351-362.

Nagel, Thomas: Moral Questions. Cambridge 1979.

Rappaport, Roy: Ritual and Religion in the Making of Humanity. Cambridge 1999.

Rosati, Massimo (et al., eds.): Multiple Modernities and Post-Secular Societies. London 2012.

Seligman, Adam B. (ed.): Religious Education and the Challenge of Pluralism. Oxford 2014.

Id.: "Il secolarismo: condizione necessaria della scienza sociale?", in: Belarinelli, Sergio/ Allodi, Leonardo / Gattamorrta, Lorenza (eds.): Verso Una Societa Post-Secolare? Soveria Manelli 2009, pp. 57-82.

Id.: "Secularism, Liberalism and the Problem of Tolerance: the case of the USA", in: Theoria: A Journal of Social and Political Theory (115) 2008, pp. 17-31. 
Id.: "The Failure of Socialism in the United States; a reconsiderataion", in: Eisenstadt, Samuel / Roniger, Luis / Seligman, Adam: Centre Formation, Protest Movements and Class Structure in Europe and the United States. London 1987, pp. 90-117.

Seligman, Adam B. / Weller, Robert P. / Puett, Michael J. / Simon, Bennett: Ritual and its Consequences: An Essay on the Limits of Sincerity. New York 2008.

Seligman, Adam B. / Weller, Robert: Rethinking Pluralism: Ritual, Experience and Ambiguity. New York 2012.

Shorto, Russell: "Faith at Work", in: New York Times Magazine, 31 October 2004.

Stein, Rokkan: "Dimensions of State Formation and Nation-Building: A Possible Paradigm for Research Variations within Europe", in: Tilly, Charles (ed.): The Formation of National States in Western Europe. Princeton 1975, pp. 562-600.

Taylor, Charles: A Secular Age. Cambridge 2007.

Voegelin, Eric: The New Science of Politics: An Introduction. Chicago 1987.

Volf, Miroslav / Bass, Dorothy: Practicing Theology: Beliefs and Practices in Christian Life. Grand Rapids 2002.

Wei-Ming, Tu: "The Search for Roots in Industrial East Asia: The Case for Revival”, in: Marty, Martin E. / Appleby, Scott: Fundamentalisms Observed. Chicago 1991.

Weller, Robert: "Divided Market Culture in China", in: Hefner, Robert (ed.): Market Culture: Society and Morality in the New Asian Capitalisms, Boulder 1998.

Id.: "Worship, Teachings and State Power in China and Taiwan", in: Kirby, William (ed.): Realms of Freedom in Modern China. Stanford 2004, pp. 285-314.

Yang, Fenggan: Religion in China: Survival and Revival under Community Rule. New York 2011.

\section{Internet Sources}

AlIraqui: Anti Shia Convention. April 25 2014, available at: http://www.aliraqi.org/fo rums/showthread.php?t=105917 [11.05.2014].

The Star: Islamic scholars experience diversity of Muslim practices at $\mathrm{U}$ of $\mathrm{T}$ summer program. Available at: http://www.thestar.com/news/gta/2013/08/25/islamic_schol ars_experience_diversity_of_muslim_practices_at_u_of_t_summer_program.html. 